\title{
Robert Garnier, Les Juives
}

\section{Michele Mastroianni}

\section{Q OpenEdition}

\section{Journals}

\section{Edizione digitale}

URL: http://journals.openedition.org/studifrancesi/9478

DOI: $10.4000 /$ studifrancesi.9478

ISSN: 2421-5856

\section{Editore}

Rosenberg \& Sellier

\section{Edizione cartacea}

Data di pubblicazione: 1 décembre 2007

Paginazione: 641

ISSN: 0039-2944

\section{Notizia bibliografica digitale}

Michele Mastroianni, «Robert Garnier, Les Juives», Studi Francesi [Online], 153 (LI | III) | 2007, online dal 30 novembre 2015, consultato il 08 janvier 2021. URL: http://journals.openedition.org/studifrancesi/ 9478 ; DOI: https://doi.org/10.4000/studifrancesi.9478

\section{Questo documento è stato generato automaticamente il 8 janvier 2021.}

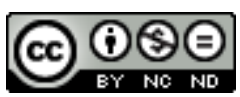

Studi Francesi è distribuita con Licenza Creative Commons Attribuzione - Non commerciale - Non opere derivate 4.0 Internazionale. 


\title{
Robert Garnier, Les Juives
}

\author{
Michele Mastroianni
}

\section{NOTIZIA}

ROBERT GARNIER, Les Juives, édition présentée, établie et annotée par Michel JEANNERET, Paris, Gallimard, 2007 («Folio Théâtre», n. 106), pp. 195.

1 Dopo la recente edizione critica a cura di Sabine Lardon (Paris, Champion, 20042), Michel Jeanneret pubblica un'edizione annotata e accompagnata da un utile dossier (come è nell'uso della collezione «Folio, théâtre») che comprende i seguenti capitoli: «La vie et l'œuvre de Garnier», "Sources et modèles», "Les 'Juives' à la scène». L'interessante Préface (pp. 7-33) illustra i problemi suscitati dalla tragédie sainte cinquecentesca, in particolare, per quanto riguarda Les Juives, il rapporto con il modello della tragedia classica greca e latina, la nozione di tragico elaborata nella tragedia biblica e, infine, l'elaborazione di un nuovo linguaggio adatto al genere della tragedia sacra. 